\title{
Social Media as a Dialogical Communication Tool: Izmir Metropolitan Municipality Example
}

\author{
Zekiye Beril Akıncı Vural ${ }^{1}$
}

(D) 0000-0002-4902-4973

\section{Gül Coşkun Değirmen 2*}

(D) 0000-0001-7535-2754

\author{
Sezen Ünüvar ${ }^{3}$ \\ (D) 0000-0002-3605-9093 \\ ${ }^{1}$ Faculty of Communication, Ege University, TURKEY \\ ${ }^{2}$ Serik Faculty of Business Administration, Akdeniz University, TURKEY \\ ${ }^{3}$ Institute of Social Sciences, Ege University, TURKEY \\ * Corresponding author: coskungul@gmail.com
}

Citation: Akıncı Vural, Z. B., Coşkun Değirmen, G., \& Ünüvar, S. (2022). Social Media as a Dialogical Communication Tool: Izmir Metropolitan Municipality Example. Online Journal of Communication and Media Technologies, 12(1), e202210. https://doi.org/10.30935/ojcmt/11557

ARTICLE INFO

Received: 20 Oct 2021

Accepted: 22 Dec 2021

\section{ABSTRACT}

Social media platforms enable organizations to deliver their messages to their target audiences much faster and more economically than traditional media channels. This new communication area also offers corporations unique opportunities by providing a dialogue-based communication opportunity with their stakeholders. The aim of this study is to examine how the social media accounts of Izmir Metropolitan Municipality, the third biggest city of Turkey, is used in terms of dialogical communication. Within this context, the article discusses how much the official social media accounts of İzmir Metropolitan Municipality include dialogic principles and how much dialogic communication with followers is achieved. Within the framework of the dialogical communication criteria developed by Kent and Taylor (1998), quantitative content analysis was carried out for the Twitter, Instagram, and Facebook accounts of the said municipality. The social media accounts of the municipality with a high follower rate were found to be successful in dialogic principles that usefulness of information, ensuring revisits, ease of interface and keeping visitors. However, the communication with the followers was found insufficient in Twitter in terms of the dialogic loop principle, and unsuccessful in Facebook and Instagram. The fact that the social media accounts of the Izmir Metropolitan Municipality are not supportive of the dialogue gives the corporation a negative image. For this reason, it is of great importance for the corporation to fulfill the principle of the dialogical loop as soon as possible.

Keywords: dialogical communication, social media, public relations, Izmir

\section{INTRODUCTION}

Globalization has paved the way for the development of communication technologies. One of these technologies is the internet. Thanks to the Internet, databases, and computers all over the world are interconnected. Interactive communication has been established with the internet, which has the ability to publish and share all kinds of data in different environments. However, before Web 2.0, users were evaluating the limited options available to them. Since the media was monopolized by a few large groups, all their products were far from interaction and communication was also one-way (Şimşek, 2016, p. 830-831). With the emergence of Web 2.0 technology in the early 2000s, the concept of social media has entered our lives. This new media field, which offers a new communication form to both individuals and corporations over Internet, has become more important day by day. Because, internet users stopped being individuals consuming what is offered to them, and become individuals who transform and share information in an interactive 
environment by being involved in content production. These developments in communication technologies have led corporations to reconsider their communication strategies. Thanks to the development of this new technology, the internet environment has become a great power as it allows users to produce and share content while increasing the number of users. Corporations that discovered this power first turned to search engines and Google, then found blogs and social networking sites, and eventually turned to social media tools that include millions of people without time and place limits in order to reach their target audiences (Yenicıktı, 2016, p. 93).

More than 20-year time course after Kent and Taylor (1998) proposed the principles of dialogic communication, these principles have become an important perspective for examining web-based corporate communication and relationship management strategies. These principles have been adapted and applied to the websites of Fortune 500 companies, public relations agencies, blogs, and new web-based communication platforms such as Facebook, Twitter, and YouTube (Wirtz \& Zimbres, 2018, p. 5-6). In other words, dialogic communication principles designed for websites in the first place are also used in blogs and social networks today. In our age of increasing digitalization, many corporations have started to adopt and use social media as a part of their communication efforts. Thanks to the popularity of social media among the public, corporations have begun to interact with their public in personal ways. Thus, the corporation had the chance to positively affect the thoughts and evaluations of the public (Thelen \& Men, 2018, p. 1-6).

Profit or non-profit, corporations that headed towards social media platforms which offer many opportunities to the user compared to traditional media tools, had to move their public relations activities to this channel in order to maintain their existence. This new communication method that is dominated by dialogical communication has opened a new page in the communication processes of corporations with their stakeholders.

The fact that corporation develop their relations with their target audiences thanks to social media has attracted the attention of many public relations experts. In academic studies to examine this interaction, researchers have used dialogic theory as a theoretical framework (Wang \& Yang, 2020, p. 2). Social networking favors a participatory and balanced communication model between the corporation and the public. In other words, this communication model is based on conversation, not persuasion. There are two basic elements of communication in social networks. The first is that the corporation publishes its own content by constantly updating these platforms. The second is to maintain the interaction it has captured through the dialogue it establishes with its public through social media platforms. Social networks have ideal conditions to encourage dialogic communication. In addition to capturing interaction with the public of the corporation, it also allows users to interact among themselves (Capriotti \& Losada-Díaz, 2018, p. 643). Public relations should basically aim to direct the interaction between the corporation and its stakeholders within the framework of the corporation's mission, vision and strategic goals. Establishing a relationship with its stakeholders and maintaining this relationship with communication and interaction enable the corporation to cooperate with its stakeholders.

The basis of this mutually beneficial relationship for the corporation and stakeholders is based on dialogic communication (Çetintaş, 2019, p. 84). The importance of dialog-based communication has been understood by many corporations today, and there are many researches on this subject both in national and international literature. In this context, it is inevitable for corporations that want to use the many opportunities of dialogic communication through social media platforms for their own benefit, to create their public relations strategies with this understanding.

\section{DIALOGICAL COMMUNICATION THEORY}

The word "dialogue" is defined as follows in the dictionary: "conversation; speech of two or more persons in works such as play, novel, story, etc.; work written on the basis of speech; agreement, adaptation or working in this way" (Türk Dil Kurumu [Turkish Language Society], 2020). Dialogue, which is a process, should be spread over a long period of time in separate parts and should be based on mutual conversation. Dialogue is the process of understanding how the other person thinks what they think and expressing yourself in the same way. What is expected with the two groups expressing themselves through dialogue is for some common grounds, mutual respect and an attitude of goodwill to be discovered. Being able to think in the same way 
and discover that thoughts can change in some cases is also among those expected by means of dialogue, which is considered as a productive process by the participants (Wierzbicka, 2006, p. 689-690). Seen as the most ethical form of communication and the central way of distinguishing truth from lies, dialogue consists of 5 features. These features are; mutuality, intimacy, empathy, risk and commitment (Kent \& Taylor, 2002, p. 22-25).

The theory and research on dialogue is based on the stimulating text "I and Thou" by Martin Buber, who was one of the first relational philosophers to consider the relationship a special right of the individual, almost a century ago. According to Buber, who believes that human interactions should be motivated by genuine interest in the other person, intimacy and acceptance of others are accepted as prerequisites for interaction. Many scholars from the fields of feminism, language, psychology, philosophy, critical theory, and others, following in the footsteps of Buber, have concentrated on the value of dialogical public relations (Buber, 1970 as cited by Kent \& Lane, 2017, p. 569-570). Carl Rogers is also considered to be one of the earliest influential dialogue theorists due to his contributions to dialogue. Rogers' famous phrase "unconditional positive regard" was quoted as a defining feature of dialogical communication (Rogers, 1992 as cited by Kent \& Lane, 2017, p. 570). Ronald D. Laing, on the other hand concentrated on another important feature of the dialogue, recognise and to be recognized (Laing, 1969 as cited by Kent \& Lane, 2017, p. 570).

The earliest work in which dialogue was evaluated as a theory of public relations belongs to Ron Pearson and he emphasized the importance of dialogical system for ethical public relations practice in his doctoral dissertation titled "A Theory of Public Relations Ethics" (Pearson, 1989 as cited by Kent \& Taylor, 2002, p. 23). With Pearson's death in 1989, his work on synthesizing public relations ethics and dialogue was interrupted. About 10 years after Pearson's articles on dialogue, Carl Botan has defined dialogue as a stance, orientation or basis rather than a special technique in communication (Botan, 1997, p. 192 as cited by Kent \& Taylor, 2002, p. 23).

The dialogical approach has been developed by various studies of Kent and Taylor $(1998,2002)$. Kent and Taylor presented a theoretical framework that will, through the Internet, enable the development and maintenance of relations between the corporation and the public categories within the framework of dialogical principles containing the basic principles of the concept of dialogue (Özdemir \& Yamanoğlu, 2010, p. 12).

According to Kent and Taylor (1998); most public relations theories are based on Grunig and Hunt's 4 models of public relations: press agency, public information, two-way asymmetric, and two-way symmetrical communication (Grunig \& Hunt, 1984 as cited by Kent \& Taylor, 1998, p. 323). Grunig argued that the most important of these models is two-way symmetrical communication (Guring, 1992 as cited by Kent \& Taylor, 1998 , p. 323). The relationship between two-way symmetrical communication and dialogical communication can be seen as the process and the product. The theoretical necessity of the two-way symmetrical communication model is to provide the necessary tools for an interactive communication between the corporation and the public. Dialogical communication, on the other hand, refers to a relationship-based type of interaction (Kent \& Taylor, 1998, p. 323). In a relationship-based public relations model, it is possible to produce mutual understanding and benefit by focusing on the common interests and goals of the corporation and the public (Ledingham, 2003, p. 193). Briefly, the model of Grunig and Hunt's two-way symmetrical communication model, only explains a linear communication process between the source and the receiver. Dialogical communication theory, on the other hand, emphasizes the mutually developed relationship and interaction process beyond this model (Okmeydan, 2019, p. 55).

According to Kent and Taylor $(1998,2002)$, relations between the public and corporations can be created, through the World Wide Web (www), and this relation can be adapted and developed. The five principles that ensure the successful integration of dialogical public relations and the World Wide Web are as follows (Capriotti \& Kuklinski, 2012, p. 620; Kent and Taylor, 1998, p. 325-329):

1. Dialogical loop

The start point of dialogical communication between the corporation and the public is a feedback loop. By means of dialogical loop, the public can question the corporation, and the corporation has the chance to answer their questions, concerns and problems. Dialogical public relations on internet requires professionalism and communication skills, as it does for public relations professionals using 
traditional media tools. For this, certain people in the public relations personnel should be assigned to this job.

The dialogical loop, along with being the framework for dialogical communication, is also the cornerstone that expresses creativity for the World Wide Web. By means of the dialogical loop adapted to a corporate internet environment, the goal of creativity can be achieved, and the platform is made efficient for mutual relations. Dialogical loop has developed over the years and has now adopted a broader, continuous, and balanced understanding of interaction.

2. Usefulness of information

Sites are visited because they have continual value. This feature forms the basis of a dialogical relationship. Because, public starts to rely on the corporation's site to obtain useful and reliable information. It is important that the website, which serves a public relations function, is easily accessible by all public. The corporation can improve its relations with the public by making the useful information on its website accessible. Another issue that needs to be taken into account is that if dialogue is to be established, then the questions and concerns of the public should be addressed.

3. Ensuring revisits

Sites with limited information do not have the attractiveness to be revisited. For this reason, sites need some attractive features such as containing up-to-dateness information, share place for new comments, and changing topics, and form sections for question and answer by online experts in order to ensure revisits. A number of features such as frequently asked questions (FAQs), easy-to-download information, technical, or special information that can be requested by mail or e-mail are also among the tools that encourage revisits.

4. Ease of interface

It is important that the use of websites is understandable. Therefore, the information contained in the table of contents should be well organized and hierarchical. Visitors should not have difficulties in discovering what information a site contains and where links direct. Most of the site's content should be textual, as text loads faster than graphics.

5. Keeping the visitors

To make sure that the visitors do not leave the page, web designers should place sponsored or corporate ads at the bottom of pages or behind other clearly marked links. When visitors leave the site through such a link, they may not return. These types of ads also slow down the functioning of the site. For this reason, sponsored advertisements should be avoided, or a strategic placement should be made so as not to distract the visitor.

\section{SOCIAL MEDIA AS A DIALOGICAL COMMUNICATION TOOL}

Social media brings the concept of dialogue to the agenda of public relations in a vital way. Social media, which equates the source and the receiver in a way, also has interpersonal communication features. As the separation between the source and the receiver is reduced by means of social media where there is a quick feedback opportunity, none of the parties has the complete control. For this reason, it is predicted that the communication model created on this platform should be dialogical (Köseoğlu \& Köker, 2014, p. 219).

In the world of public relations, social media is considered as a revolutionary force that changes the ways of thinking and distorts the practice of public relations. Public relations practitioners quickly embraced social media, which is seen as a new form of public relations and transferred traditional media skills and techniques to this medium. It is thought that, if used to its full potential, social media will make public relations practice more global, strategic, bidirectional, and interactive, symmetrical or dialogical and socially responsible (Grunig, 2009, p. 1).

Social media applications having the mobile compatibility feature so that they can be used on smart phones has made it easier for these networks to be included in all areas of life. By means of the social media, which provides the opportunity to establish a dialogue between the corporations and the public, a new interactive process has now begun in social networks such as Twitter, Instagram and YouTube, in which 
symmetrical relations are established in line with corporate purposes (Yağmurlu, 2013, p. 97). In other words, the way of communication between corporations and their stakeholders has changed with the cooperation, participation and interaction opportunities provided by social media in today's world. For this reason, today social media is a strategic communication partner that offers unique possibilities to organizations. Social media platforms provide an opportunity for corporations to have a real dialogue with the public. Today, corporations not only have to take place in social media, but also make more efforts to encourage dialogue with the public (Gomez Vasquez \& Soto Velez, 2011, p. 157-163).

Although the social media, which has entered our lives with Web 2.0 technology, has a structure similar to face-to-face communication, communication in social media can only be dialogical if dialogical features are realized. The point to be noted here is that when talking about dialogical communication, both in public and corporate dimensions, the desire to learn about the opinion of the other party by appreciating it should be included (Yağmurlu, 2013, p. 110). New digital media is thought to force public relations practitioners to abandon the traditional one-sided, message-oriented, asymmetric, and ethnocentric practice approach, as public relations attributes have dialogical, interactive, relational and global characteristics that make it perfectly suited for the strategic management approach (Grunig, 2009, p. 6).

As a result, social media, where monologue is replaced by dialogue, is no longer an area to be ignored by corporations. However, some features that make social media important, such as dialogue, participation, openness, interactivity, and mutuality, can sometimes have disadvantages for corporations. For this reason, it is critical for professionals using social media to develop a very good strategy and to carry out sustainable and corporately beneficial practices (Şengöz \& Eroğlu, 2017, p. 206).

\section{AN ANALYSIS ON SOCIAL MEDIA ACCOUNTS OF IZMIR METROPOLITAN MUNICIPALITY WITHIN THE CONTEXT OF DIALOGICAL COMMUNICATION}

\section{The Aim of the Research}

In the study, the corporate framework of the dialogical communication concept was determined and the role of social media as a dialogical communication tool was defined. The aim of the research is to reveal how İzmir Metropolitan Municipality, the third largest city of Turkey, uses its social media accounts in terms of dialogical communication.

\section{Research Questions}

The research questions are as follows:

RQ1: What issues does Izmir Metropolitan Municipality share on its official social media accounts?

RQ2: What kind of content does Izmir Metropolitan Municipality share on its official social media accounts in terms of form?

RQ3: Does the Facebook account of Izmir Metropolitan Municipality include dialogical communication principles?

RQ4: Does the Twitter account of izmir Metropolitan Municipality include dialogical communication principles?

RQ5: Does the Instagram account of İzmir Metropolitan Municipality include dialogical communication principles?

\section{Research Method and Sample}

In the research, quantitative content analysis was conducted for Twitter, Instagram, and Facebook accounts of Izmir Metropolitan Municipality within the framework of the dialogical communication principles developed by Kent and Taylor (1998, p. 321-331). In this process, while determining the level of dialogical communication in İzmir Metropolitan Municipality, table adaptation developed by Okmeydan (2019) and Yagmurlu (2013) was used, all of which were based on the original scale of dialogical principles of Kent and Taylor (1998, p. 326-331). The sample of the research is izmir Metropolitan Municipality, which is one of the first three biggest metropolitan municipalities of Turkey. 


\section{Limitations of the Research}

In the study, a period when citizens' questions on their posts on the social media accounts of the Izmir Metropolitan Municipality become intense due to the reasons such as the pandemic restrictions and the Izmir earthquake on October 30, 2020 were discussed. The posts on Twitter, Instagram, and Facebook accounts of İzmir Metropolitan Municipality between October 5 and December 5, 2020 covering before and after this period, were analysed. Discussing the posts made in the 2-month period constitutes the limitation of the research. The research was completed in February 2021.

\section{FINDINGS}

\section{RQ1: What Issues Does İzmir Metropolitan Municipality Share on Its Official Social Media Accounts?}

In Table 1, it is seen that Izmir Metropolitan Municipality shared a total of 214 posts on its Facebook account, 220 posts on its Twitter account, and 173 posts on its Instagram account in this 2-month period. On the basis of the issues, the contents falling under the category of "Corporate News and Announcements" were shared with 136 posts on Facebook, 168 posts on Twitter, and 133 posts on Instagram. Under this category are the posts made by the municipality to announce the news about its routine works and the developments related to its activities.

Table 1. Distribution of topics of posts on Facebook, Twitter, and Instagram accounts of Izmir Metropolitan Municipality

\begin{tabular}{|c|c|c|c|c|c|c|}
\hline \multicolumn{7}{|c|}{ Distribution of topics of posts on Facebook account } \\
\hline Advertisement/Promotion & $\begin{array}{l}\text { Corporate news \& } \\
\text { announcements }\end{array}$ & Information & Establishing a relation & Entertainment & Other & Total \\
\hline- & 136 & 34 & 4 & - & 13 & 214 \\
\hline \multicolumn{7}{|c|}{ Distribution of topics of posts on Twitter account } \\
\hline Advertisement/Promotion & $\begin{array}{l}\text { Corporate news \& } \\
\text { announcements }\end{array}$ & Information & Establishing a relation & Entertainment & Other & Total \\
\hline- & 168 & 35 & 4 & - & 13 & 220 \\
\hline \multicolumn{7}{|c|}{ Distribution of topics of posts on Instagram account } \\
\hline Advertisement/Promotion & $\begin{array}{c}\text { Corporate news \& } \\
\text { announcements }\end{array}$ & Information & Establishing a relation & Entertainment & Other & Total \\
\hline- & 133 & 25 & 3 & - & 12 & 173 \\
\hline
\end{tabular}

In the second place are posts under the subject of "Information" with 34 posts on Facebook, 35 posts on Twitter, and 35 posts on Instagram. It is seen that these posts are mainly about informing citizens about the process after the İzmir earthquake on October 30, 2020.

In the third place are posts under the title "Other" with 13 posts on Facebook and Twitter, and 12 post on Instagram. These posts consist of congratulatory or commemorative messages for special days.

In the last place are posts on "Relationship Building", which are made to interact or dialogue with the followers and get feedback. In this category, there are 4 posts on Facebook, 4 posts on Twitter, and 3 posts on Instagram.

In line with this information, it can be said that the posts made by the İzmir Metropolitan Municipality on social media accounts are grouped under the headings of corporate news and announcements, information, relationship building and other topics.

\section{RQ2: What Kind of Content Does İzmir Metropolitan Municipality Share on Its Official Social Media Accounts in Terms of Form?}

When the posts of İzmir Metropolitan Municipality on Facebook, Twitter, and Instagram are evaluated in terms of form (Table 2), it is seen that they are predominantly text, photograph and video. All of the Instagram posts consist of a photo or video and additionally a descriptive text on the photo or video. On Facebook and Twitter, on the other hand, it is seen that there are posts with photos or videos and additionally explanatory text on the photo or video, and besides, there are 2 posts on Facebook and 6 posts on Twitter that only consist 
of an explanatory text. In other words, it is understood that visual elements are used in the majority of the messages that are intended to be conveyed to the audience.

Table 2. Content sharing distributions of İzmir Metropolitan Municipality in terms of form

\begin{tabular}{lcccc}
\hline & Text & Photograph & Video & Other \\
\hline Facebook & 214 & 112 & 100 & - \\
Twitter & 220 & 116 & 98 & - \\
Instagram & 173 & 107 & 66 & - \\
\hline
\end{tabular}

\section{RQ3: Does the Facebook Account of İzmir Metropolitan Municipality Include Dialogical Communication Principles?}

The official social media accounts of İzmir Metropolitan Municipality were analysed within the framework of the principles of dialogical loop, usefulness of information, revisit, interface, and keeping the visitors. The data obtained in terms of dialogical communication as a result of the analyses made on the Facebook account are given in Table 3, Table 4, Table 5, and Table 6.

Table 3. Evaluation of Izmir Metropolitan Municipality's Facebook account in terms of dialogical loop

\begin{tabular}{ccc}
\hline Dialogical loop & Number of follower comments & 9,702 \\
& Number of answered comments & 0 \\
& Number of likes & 134,035 \\
Number of reposts & 21,280 \\
\hline
\end{tabular}

Table 4. Evaluation of İzmir Metropolitan Municipality's Facebook account in terms of usefulness of information

\begin{tabular}{ccc}
\hline Usefulness of information & Times corporate news/announcements are posted & 163 \\
& Times information are posted & 34 \\
Times relations are established & 4 \\
Other & 13 \\
\hline
\end{tabular}

Table 5. Evaluation of Izmir Metropolitan Municipality's Facebook account in terms of revisits

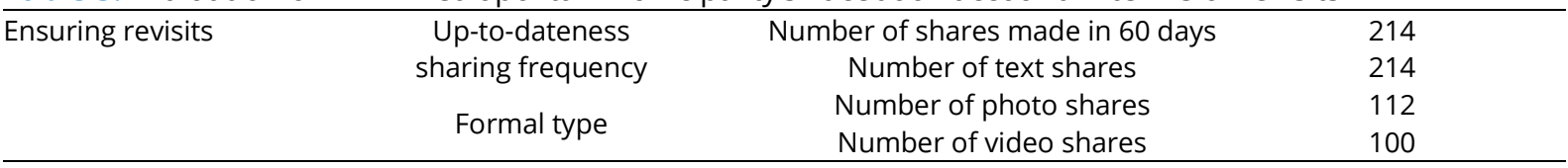

Table 6. Evaluation of İzmir Metropolitan Municipality's Facebook account in terms of keeping the visitors

\begin{tabular}{lccc}
\hline Keeping the visitors & Number of followers & 1 . day & 181,754 \\
& (change in 60 days) & 60. day & 184,797 \\
\hline
\end{tabular}

When the posts made by the Izmir Metropolitan Municipality on Facebook are analysed within the framework of the dialogical loop, which is the first principle of dialogical communication; it was observed that 9,702 followers commented on the 214 posts the municipality shared, none of these comments were answered, and the posts outside the research dates were also not answered. While the posts were liked 134 thousand 35 times in total, they were re-shared 21 thousand 280 times on the followers' own accounts. In line with these data, it can be stated that there is a significant interaction on the municipality's Facebook account, but there is no dialogical loop as no response is given to the comments of the followers.

In terms of the usefulness of information, which is the second principle of dialogical communication, it is seen that the posts shared mainly consist of corporate news and announcements. These posts are important for the audience considering the numbers of likes and reposts. Accordingly, the posts provide useful information to the followers.

The third principle, ensuring revisits, is explained by the frequency of sharing and the formal type of sharing. İmir Metropolitan Municipality shared 214 posts in the 2-month period within the scope of the research. These figures reveal that the municipality's Facebook account is up-to-date. 2 of the municipality's 214 posts are made up of only the explanation text, 112 of them with photos, and 100 of them with video and explanation text. In light of these data, it can be stated that Izmir Metropolitan Municipality offers a successful work in ensuring revisits by preserving the interest of its followers on its Facebook account. 
Within the framework of the ease of the interface, which is the fourth principle of dialogical communication, İzmir Metropolitan Municipality has made customizations as allowed by the Facebook application. They arranged the profile photo and cover page in harmony with other social media applications, and this arrangement was created in accordance with Facebook's mobile application. This reveals the impression that the interface of the Facebook application has been successfully adapted by the İzmir Metropolitan Municipality.

The last principle of dialogical communication is keeping the visitors. Within the scope of this principle measured by the number of followers in the 2-month period in which the research was conducted, the number of followers of the İzmir Metropolitan Municipality increased from 181,754 to 184,797. Keeping its visitors, the municipality has also achieved a significant increase in the number of visitors.

\section{RQ4: Does the Twitter Account of İzmir Metropolitan Municipality Include Dialogical Communication Principles?}

The data obtained in terms of dialogical communication as a result of the analyses made on the Twitter account of Izmir Metropolitan Municipality are given in Table 7, Table 8, Table 9, and Table 10.

Table 7. Evaluation of İzmir Metropolitan Municipality's Twitter account in terms of dialogical loop

\begin{tabular}{ccc}
\hline Dialogical loop & Number of follower comments & 5,602 \\
& Number of answered comments & 194 \\
& Number of likes & 360,453 \\
& Number of retweets & 90,297 \\
\hline
\end{tabular}

Table 8. Evaluation of İzmir Metropolitan Municipality's Twitter account in terms of usefulness of information Usefulness of information $\quad$ Times corporate news/announcements are posted 168 Times information are posted $\quad 35$ Times relations are established $\quad 4$ Other 13

Table 9. Evaluation of İzmir Metropolitan Municipality's Twitter account in terms of revisits

\begin{tabular}{|c|c|c|c|}
\hline Ensuring revisits & $\begin{array}{l}\text { Up-to-dateness } \\
\text { sharing frequency } \\
\text { Formal type }\end{array}$ & $\begin{array}{c}\text { Number of shares made in } 60 \text { days } \\
\text { Number of text shares } \\
\text { Number of photo shares } \\
\text { Number of video shares }\end{array}$ & $\begin{array}{c}220 \\
220 \\
116 \\
98 \\
\end{array}$ \\
\hline
\end{tabular}

Table 10. Evaluation of İzmir Metropolitan Municipality's Facebook account in terms of keeping the visitors

\begin{tabular}{lccc}
\hline Keeping the visitors & Number of followers & 1. day & 353,085 \\
& (change in 60 days) & 60 . day & 380,436 \\
\hline
\end{tabular}

On the posts shared by the Izmir Metropolitan Municipality on its Twitter account, 5 thousand 602 comments were made by the followers. 194 of these comments were responded to via the Izmir HIM account, which is the official Twitter account of Izmir Metropolitan Municipality Citizen Communication Centre. The posts were liked 360 thousand 453 times and retweeted 90 thousand 297 times. When the first principle of dialogical communication is evaluated within the framework of the dialogical loop, the posts shared by the Izmir Metropolitan Municipality on Twitter have received significant interaction, and even though the followers' comments are responded to at a low level through İzmir HIM, a dialogical loop has been achieved.

The Municipality shared mainly corporate news and announcements on its Twitter account as well. Considering the high rate of likes, comments, and retweets to these posts, it turns out that the information provided is useful according to the principle of usefulness of information.

It has been observed that the municipality, which made 220 posts in 2 months in terms of the principle of ensuring revisits, keeps its Twitter account extremely up-to-date. As it is catchy for the followers that 116 of the posts are photos and 98 of them are videos, the principle of ensuring revisits has been achieved successfully.

Looking at the interface, which is the fourth principle of dialogical communication, İzmir Metropolitan Municipality has made the personalization settings allowed by the application. The profile photo and cover 
design of the municipality's account has been prepared in a common design with other applications. These arrangements were made in harmony with the mobile option of the Twitter interface.

Keeping visitors, which is the fifth principle of dialogical communication, defines the change of followers during the 2-month period in which the research was conducted. Accordingly, İzmir Metropolitan Municipality has achieved a significant success by increasing the number of followers from 353 thousand 85 on 5 October 2020 to 380 thousand 436 on 5 December 2020.

\section{RQ5: Does the Instagram Account of İzmir Metropolitan Municipality Include Dialogical Communication Principles?}

The data obtained in terms of dialogical communication as a result of the analyses made on the Instagram account of Izmir Metropolitan Municipality are given in Table 11, Table 12, Table 13, and Table 14.

Table 11. Evaluation of İzmir Metropolitan Municipality's Instagram account in terms of dialogical loop

\begin{tabular}{|c|c|c|c|}
\hline \multirow[t]{4}{*}{ Dialogical loop } & Number of follower comments & 4,661 & 9702 \\
\hline & Number of answered comments & 1 & 0 \\
\hline & Number of likes & 347,758 & 134,035 \\
\hline & Number of reports & 0 & 21,280 \\
\hline
\end{tabular}

Table 12. Evaluation of İmir Metropolitan Municipality's Instagram account in terms of usefulness of information

\begin{tabular}{ccc}
\hline Usefulness of information & Times corporate news/announcements are posted & 133 \\
& Times information are posted & 25 \\
Times relations are established & 3 \\
Other & 12 \\
\hline
\end{tabular}

Table 13. Evaluation of İmir Metropolitan Municipality's Instagram account in terms of revisits

\begin{tabular}{lccc}
\hline Ensuring revisits & Up-to-dateness & Number of shares made in 60 days & 173 \\
& sharing frequency & Number of text shares & 173 \\
& Fumber of photo shares & 107 \\
& Formal type & Number of video shares & 66 \\
\hline
\end{tabular}

Table 14. Evaluation of Izmir Metropolitan Municipality's Instagram account in terms of keeping the visitors

\begin{tabular}{llll}
\hline Keeping the visitors & Number of followers & 1. day & 307,974 \\
& (change in 60 days) & 60. day & 334,000 \\
\hline
\end{tabular}

4 thousand 663 comments were made on the posts of Izmir Metropolitan Municipality on its Instagram account. The posts received a high number of likes of 347 thousand 758 . However, the municipality responded to only one of the comments made through the Instagram account of the IZSU General Directorate of the municipality, so the principle of the dialogical loop was not successful.

Izmir Metropolitan Municipality has mostly shared corporate news and announcements on its Instagram account, as in other social media accounts. Together with these shares receiving a high rate of likes and comments, it was seen that the information was useful.

The municipality shared 173 posts on its Instagram account in the 2-month period covering the research. These sharing numbers reveal the up-to-date of the Instagram account. As in other social media accounts, the interest of the audience was preserved, and the principle of ensuring revisits was realized by sharing with photos in 107 and with videos in 66 of 173 posts.

Within the scope of the interface principle of dialogical communication, it has been determined that the Instagram interface of Izmir Metropolitan Municipality is carried out in harmony with the mobile option.

The principle of keeping the visitors of dialogical communication refers to the change in the number of visitors between the dates of the research. The number of followers of the Izmir Metropolitan Municipality, which was 307 thousand 974 at the beginning of the research, was recorded as 334 thousand at the end of the research. In addition to keeping the number of visitors, the municipality has successfully fulfilled the principle of keeping the visitors by providing a significant increase in the number of visitors. 


\section{CONCLUSIONS}

In today's world where communication technologies continue to develop rapidly, social media has now become vital for public corporations as well as the private sector.

While accessing information is now easier for everyone, municipalities need dialogue-based communication in order to accurately explain to the people of the region the projects and policies they will implement, to inform the public, to provide support by creating consensus and to maintain this support. Therefore, the importance of public relations activities based on two-way symmetrical understanding, relationship and dialogical communication increases day by day (Engin \& Akgöz, 2016, p. 100). In social media, municipalities can establish emotional bonds with the public by using a sincere language. Thus, municipalities, which can have the opportunity to strengthen their corporate identity, can also take advantage of opportunities such as learning, sharing and interpreting the ideas of target audiences by means of the social media. By means of this new media that contributes to the interaction between the administration and the public, unnecessary bureaucracy is also eliminated (Solmaz \& Görkemli, 2012, p. 13).

This study has analysed to what extent İzmir Metropolitan Municipality realizes dialogical communication in its social media accounts. Looking at the dialogical communication principles developed by Kent and Taylor (1998, p. 326-331) on Facebook, Twitter, and Instagram accounts of the municipality, it is seen that the principles of usefulness of information, ensuring revisit, interface and keeping visitors are fulfilled in all three accounts. While the principle of the dialogical loop was maintained at a low level in the Twitter account, which received high interaction from the followers, the dialogical loop was not fulfilled in Facebook and Instagram, which also received high interaction from the followers, and this principle failed.

Considering that the feedback is very important for the public as well as the corporations, leaving the comments of the followers unanswered, ignoring them or making them think that they are worthless jeopardizes the sustainability of the public support as well as the image of the corporation. For this reason, Izmir Metropolitan Municipality needs to fulfil the principle of the missing dialogical loop in order to use social media accounts as a dialogical communication tool.

Author contributions: All authors were involved in concept, design, collection of data, interpretation, writing, and critically revising the article. All authors approve final version of the article.

Funding: The authors received no financial support for the research and/or authorship of this article.

Declaration of interest: Authors declare no competing interest.

Data availability: Data generated or analysed during this study are available from the authors on request.

\section{REFERENCES}

Capriotti, P., \& Kuklinski, H. P. (2012). Assessing dialogic communication through the Internet in Spanish museums. Public Relations Review, 38(4), 619-626. https://doi.org/10.1016/j.pubrev.2012.05.005

Capriotti, P., \& Losada-Díaz, J. C. (2018). Facebook as a dialogic communication tool at the most visited museums of the world. El Profesional de la Información [The Information Professional], 27(3), 642-650. https://doi.org/10.3145/epi.2018.may.17

Çetintaş, H. B. (2019). Diyalojik paydaş iletişimi için Twitter kullanımı [Using Twitter for dialogic stakeholder communication]. Anadolu Üniversitesi Sosyal Bilimler Dergisi [Anadolu University Journal of Social Sciences], 19(3), 83-96. https://doi.org/10.18037/ausbd.631980

Engin, E., \& Akgöz, B. E. (2016). Belediyelerin web sitelerinin diyalojik iletişim açısından analizi [Analysis of municipalities' websites in terms of dialogic communication]. Atatürk Iletişim Dergisi [Ataturk Communication Journal], (10), 91-110. https://dergipark.org.tr/en/pub/atauniiletisim/issue/ $33795 / 374300$

Gomez Vasquez, L. M., \& Soto Velez, I. (2011). Los medios sociales como una herramienta estratégica para la comunicación corporativa [Social media as a strategic tool for corporate communication]. Revista Internacional de Relaciones Públicas [International Journal of Public Relations], 1(2), 157-174. https://doi.org/ 10.5783/RIRP-2-2011-09-157-174

Grunig, J. E. (2009). Paradigms of global public relations in an age of digitalisation. PRism, 6(2), 1-19. http://praxis.massey.ac.nz/prism_on-line_journ.html 
Kent, M. L., \& Lane, A. B. (2017). A rhizomatous metaphor for dialogic theory. Public Relations Review, 43(3), 568-578. https://doi.org/10.1016/j.pubrev.2017.02.017

Kent, M. L., \& Taylor, M. (1998). Building dialogic relationships through the World Wide Web. Public Relations Review, 24(3), 321-334. https://doi.org/10.1016/S0363-8111(99)80143-X

Kent, M. L., \& Taylor, M. (2002). Toward a dialogic theory of public relations. Public Relations Review, 28(1), 2137. https://doi.org/10.1016/S0363-8111(02)00108-X

Köseoğlu, Ö., \& Köker, N. E. (2014). Türk üniversiteleri Twitter'ı diyalogsal iletişim açısından nasıl kullanıyor: Beş Türk üniversitesi üzerine bir içerik analizi [How Turkish universities use Twitter for dialogic communication: A content analysis on five Turkish universities]. Global Media Journal: Turkish Edition, 4(8). https://globalmediajournaltr.yeditepe.edu.tr/sites/default/files/koseoglu-koker.pdf

Ledingham, J. A. (2003). Explicating relationship management as a general theory of public relations. Journal of Public Relations Research, 15(2), 181-198. https://doi.org/10.1207/S1532754XJPRR1502_4

Okmeydan, C. K. (2019). Diyalojik iletişimin sosyal müşteri ilişkileri yönetimine katkısı: Kurumsal markalar üzerine bir araştırma [Contribution of dialogic communication to social customer relationship management: $A$ research on corporate brands] [Unpublished doctoral dissertation]. Ege University.

Özdemir, B. P., \& Yamanoğlu, M. A. (2010). Türkiye'deki sivil toplum kuruluşları web sitelerinin diyalojik iletişim kapasiteleri üzerine bir inceleme [An investigation of dialogical communication capacities of non govermental organizations' web sites in Turkey]. Ankara Üniversitesi Sosyal Bilimler Dergisi [Ankara University Journal of Social Sciences], 1(2), 3-36. https://ssrn.com/abstract=3285184

Şengöz, A., \& Eroğlu, E. (2017). Örgütlerde sosyal medya kullanımı: Sosyal medya algıları, amaçları ve kullanım alışkanlıkları [Social media use in organizations: Social media perceptions, purposes and usage habits]. Gümüşhane Üniversitesi Iletişim Fakültesi Elektronik Dergisi [Gumushane University Faculty of Communication Electronic Journal], 5(1), 503-524. https://doi.org/10.19145/gumuscomm.288789

Şimşek, G. (2016). Büyükşehir belediye başkanlarının diyalojik iletişim çerçevesinde sosyal medya uygulamaları [Social media applications of metropolitan mayors within the framework of dialogic communication]. Journal of International Social Research, 9(46), 829-839. https://doi.org/10.17719/ jisr.20164622646

Solmaz, B., \& Görkemli, H. N. (2012). Büyükşehir belediyeleri ve sosyal medya kullanımı [Metropolitan municipalities and use of social media]. Akdeniz Iletisim [Mediterranean Communication], (18). https://dergipark.org.tr/en/pub/akil/issue/48077/607855

Thelen, P. D., \& Men, R. L. (2018). Strategic use of Facebook for public engagement in higher education institutions. Public Relations Journal, 12(2), 1-27.

Türk Dil Kurumu [Turkish Language Society]. (2020). Diyalog [Dialog]. https://sozluk.gov.tr/

Wang, Y., \& Yang, Y. (2020). Dialogic communication on social media: How organizations use Twitter to build dialogic relationships with their publics. Computers in Human Behavior, 104, 106183. https://doi.org/10.1016/j.chb.2019.106183

Wierzbicka, A. (2006). The concept of 'dialogue' in cross-linguistic and cross-cultural perspective. Discourse Studies, 8(5), 675-703. https://doi.org/10.1177/1461445606067334

Wirtz, J. G., \& Zimbres, T. M. (2018). A systematic analysis of research applying 'principles of dialogic communication' to organizational websites, blogs, and social media: Implications for theory and practice. Journal of Public Relations Research, 30(1-2), 5-34. https://doi.org/10.1080/1062726X.2018.1455146

Yağmurlu, A. (2013). Diyalojik iletişim çerçevesinden Ankara Büyükşehir Belediyesi sosyal medya uygulamaları [Ankara Metropolitan Municipality social media applications within the framework of dialogic communication]. Selçuk Iletişim [Selcuk Communication], 8(1), 95-115. https://dergipark.org.tr/en/pub/ josc/issue/19026/200532

Yeniçıktı, N. T. (2016). Hakla ilişkiler aracı olarak Instagram: Sosyal medya kullanan 50 şirket üzerine bir araştırma [Instagram as a public relations tool: A study on 50 companies using social media]. Selçuk iletişim [Selcuk Communication], 9(2), 92-115. https://doi.org/10.18094/si.84410
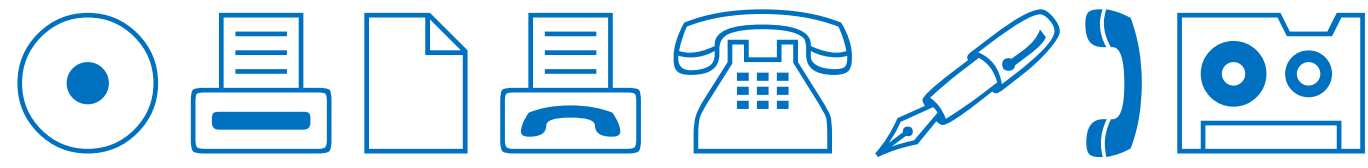